\title{
Payment Innovations, the Shadow Economy and Cash Demand of Households in Euro Area Countries
}

\author{
Hans-Eggert Reimers \\ University of Technology, Business and Design Wismar \\ Friedrich Schneider \\ Johannes Kepler University Linz \\ Franz Seitz \\ Technical University of Applied Sciences Amberg-Weiden
}

\begin{abstract}
We analyze for the first time cash holdings of private households in all euro area countries from 2002 to 2019 within a panel cointegration framework. Besides the traditional determinants of cash demand like transactions balances and opportunity costs, we concentrate on cashless payments media as substitutes to cash payments and the role of the shadow economy. Moreover, we take due account of country-specific repercussions of the financial and economic crisis of 2008/09, time series properties and distinguish between small and large countries. We find a significant and positive relationship among households' cash holdings, the volume of transactions and the size of the shadow economy irrespective of country size for all euro area countries over our sample period. Additionally, there is a substitution relationship between the accessibility and availability of cashless payments media and cash demand. And a decreasing number of ATMs reduces cash holdings. These results have important political and financial implications.
\end{abstract}

Keywords: cash, cashless payments, shadow economy, cash demand function, panel cointegration

\section{INTRODUCTION AND OVERVIEW}

Since the introduction of euro notes and coins in January 2002, cash in circulation in the euro area has been steadily increasing, both in absolute terms (nearly quadruplication from 2002 to 2019), but also relative to GDP (see Fig. 1). Its share in GDP was 2.5 times higher in 2019 than in 2002. Worldwide, this is not an exceptional development as Jobst \& Stix (2017), Bech, et al. (2018), Shirai \& Sugandi (2019), Arango-Arango \& Suáres-Ariza (2019) and Ashworth \& Goodhart (2020) have shown. What is surprising, however, is that the drivers of this dynamic evolution are not intensively studied and well understood.

The European Central Bank $(2017 ; 2018)$ estimates that about $30 \%$ of total euro cash in circulation is held outside the euro area. However, this foreign share is hard to capture (see for different efforts in this respect Bartzsch, et al, 2011a; b; 2013). And it is difficult to find reliable indicator variables which represent this effect and can be included in cash demand equations (see Fischer, et al., 2004; Bartzsch \& Seitz, 2016; Judson, 2018; Flannigan \& Parsons, 2018; Assenmacher, et al., 2019; Rua, 2019). Within a currency area, 
the bulk of cash holdings usually originates in the household sector. Of course, retailers hold cash due to the payment behavior of their customers. But they have an incentive to economize on cash holdings. Other non-financial firms and the government do not demand significant amounts of cash. ${ }^{1}$

\section{FIGURE 1 \\ CASH IN CIRCULATION IN THE EURO AREA}

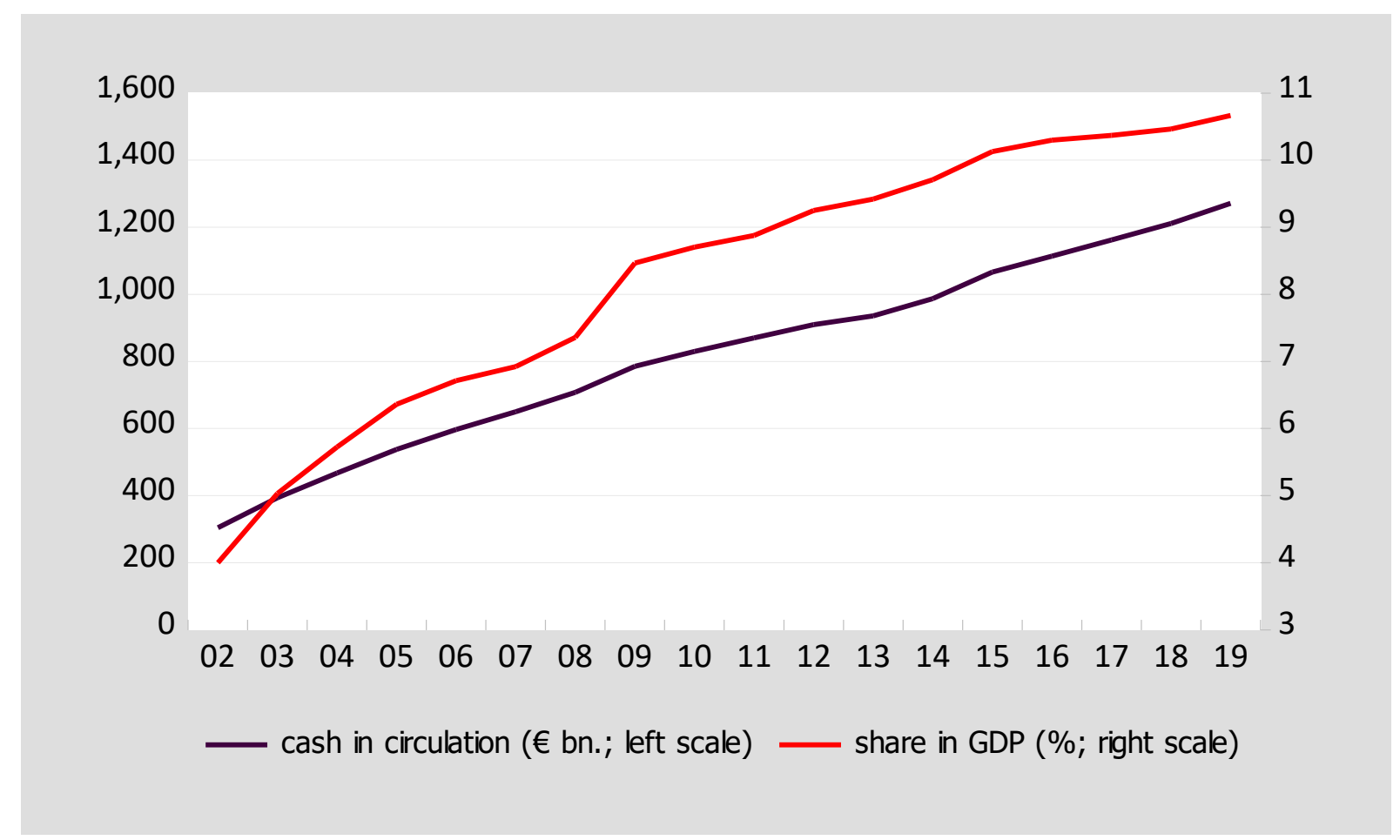

Source: ECB SDW

The individual euro area countries are quite heterogenous, both with respect to the real sector (e.g., Belke, et al., 2017) as well as to the financial (ECB, 2020) and to the payments environment (Esselink \& Hernández, 2017). The latter is especially true for the retail and household sector. For example, in terms of number of transactions, cash payments at the point-of-sale in 2016 varied between $80 \%$ or more in the southern euro area countries as well as in Germany, Austria and Slovenia, whereas in the Netherlands, Estonia and Finland, this share ranged between $45 \%$ and 54\% (Esselink \& Hernández, 2017). According to the payments statistics of the ECB, card payments per capita in 2018 fluctuate between around 50 in Italy and more than 330 in Finland.

Summarizing the points made above would necessitate and imply an analysis of cash demand of households in each euro area country. However, within a currency union, this is not an easy task as cash holdings in individual countries and by sector are usually not known. ${ }^{2}$ It has not been done so far, but this is exactly what we do in what follows. Hence, we are the first to use data from the flow-of-funds statistics of the Eurosystem which enable us to analyze the determinants of cash holdings of private households in a panel of the 19 euro area countries since 2002. Besides the traditional determinants of cash demand, i.e. the volume of transactions and opportunity costs, we concentrate on several additional factors.

The first is the shadow economy. One criticism repeatedly levelled at cash for quite some time and which still echoes today is that it is used for illegal activities in the shadow economy and encourages moonlighting, tax evasion and money laundering, in particular. It is often (implicitly) assumed in this discussion that shadow economic activities are predominantly undertaken by cash (Buiter, 2009; Sands, 2016). However, hard empirical evidence to back this hypothesis is lacking. ${ }^{3}$ In the debate about stopping 
the production of the $€ 500$ banknote, the head of the ECB's Currency Management Division stated that there is no statistically proven link between the size of the shadow economy and cash (FAZ, 2016). With respect to anonymity, Drehmann, et al. (2002) wrote: "There are many reasons why people may prefer anonymity - many of which are connected with "bad behavior". But "bad" does not always mean "illegal". It can also include the small human weaknesses we are prone to. Economic agents do not necessarily want these documented in full in the form of proof of payment." Moreover, large-scale crime that involves huge sums of money often prefers cashless means of payment (Mai, 2016). By using complicated and convoluted cross-border chains of transactions, criminals are remarkably adept at concealing the origin of their funds. To investigate how shadow economic activities affect cash demand, we construct a variable which reflects the behavior of private households in this respect. In that sense, it corresponds quite well to our cash variable.

The second is alternative payments media besides cash. The candidate series are the number of (credit and debit) cards, the number of point-of-sale terminals (POS), the number (value) of card payments and the number (value) of cashless POS transactions. With a declining share of cash payments at the POS all over Europe (see, e.g., ECB, 2018), these variables should proxy substitutes for cash and exert a negative influence on cash holdings of households. The third factor we take into account is closely related to the second one. It refers to access of cash in the form of availability of ATMs. If country-wide access to cash is not guaranteed, potential demand might not be realized (Sveriges Riksbank, 2019). However, the total effect on cash holdings is ambiguous as having less access to cash might lead consumers to hold more cash to realize their transaction needs. Therefore, it seems useful to include a variable that captures this aspect.

Fourth, crisis- and uncertainty-related as well as precautionary demand for cash. In our sample, several financial and real crises happened (e.g., the financial and economic crisis of 2008/09, the euro crisis of 2011/12). Additionally, geopolitical uncertainties have risen in the last decade. In such episodes, the demand for cash usually increases (see, e.g., Krüger \& Seitz, 2017, ch 4.2). The essential question is whether the repercussions will be only temporary or long-lasting. We try to capture these effects by dummy variables and adequate specification of the econometric model.

In summary, the goal of our paper is to shed light on the relationship between cash holdings of households in the 19 euro area countries and the volume of transactions, opportunity costs and hoarding motives, alternative means of payment, the size of the shadow economy and crisis-related as well as precautionary demand within a cash demand framework. For that purpose, we make use of panel cointegration techniques. We also distinguish between the large (Germany, France, Italy, Spain) and the smaller euro area countries. To our knowledge this kind of empirical research has not been undertaken so far.

The paper is structured as follows: It starts with a literature review on cash demand in the euro area in section 2. Section 3 presents the data and, in particular, explains the concept of households' cash holdings and the selected estimation procedure for the shadow economic variable. Moreover, the econometric methodology is briefly described. The results for the panel of 19 euro area countries are presented in section 4. Section 5 summarizes and concludes.

\section{LITERATURE REVIEW ON EURO AREA CASH DEMAND AND FOUR HYPOTHESES}

The literature on the relationship between cash in circulation in the euro area and its determinants is scarce. Either the euro area as a whole or individual country's cumulated net issues are investigated. Fischer, et al. (2004) addresses euro currency demand resorting to euro legacy banknotes while considering a breakdown into large and small-value denominations. Rua (2019) concentrates on the situation since the introduction of euro notes and coins and models each banknote denomination individually. Both studies find that all motives for holding cash are present in the euro case. In contrast, Bartzsch, et al. (2013), Bartzsch \& Seitz (2016), Deutsche Bundesbank (2018) and Rua (2018) analyze the net issues of individual euro area countries, namely Germany and Portugal. Seitz, et al. (2020) consider the net issues of a panel of euro area countries. All these papers reveal that the cash holding motives are relevant to differing degrees for the different denominations. Esselink \& Hernández (2017) present survey results on the use of cash by 
households at the point of sale (POS), i.e. it concentrates on transactions balances. Their results show that in 2016 around $79 \%$ of all payments at the POS were made with cash, with substantial differences between the euro area countries.

Several papers focus on the role of the shadow economy for cash holdings in the euro area. Since the shadow economy is not directly observable, there are some authors who use indicator variables that are positively related to it, e.g. the share of self-employment to labor force, the share of direct and indirect taxes in GDP or the unemployment rate. Using such an indicator-driven procedure, Herwartz, et al. (2016) investigate whether shadow economic activities have a measurable influence on the demand for cash in a cross section of 11 OECD countries (including Germany, Italy, Spain) from 1970 to 2012. They find within an error-correction model based on pooled data that some of these variables have a significant influence on cash demand. Deutsche Bundesbank (2019) and Bartzsch, et al. (2019) also use this approach for the case of Germany. Both analyze nine different indicators of the shadow economy within two models: one panel econometric model to explain the banknote lodgements at the Bundesbank branches and one model for domestic banknote demand. Only few of the indicators yield statistically and economically significant results. These are the share of self-employed and the number of drug-related criminal offences in the first model and the burden with taxes and social security contributions in the second. Seitz et al (2020) use the same direct estimates as in the present paper and find a significant influence of the shadow economy only for the medium denominations ( $€ 50, € 100)$ and the smaller euro area countries. However, the magnitudes are relatively modest.

By using a survey from 2016 in Austria, Schneider (2016) establishes that only about $10 \%$ of cash is used for shadow economy purposes. In looking at the situation since the beginning of the 2000 s, Takala $\&$ Virén (2010) also find that changes in cash demand do not seem to correspond to changes in existing measures of shadow economy, nor do cross-country measures correspond very well with each other. ${ }^{4}$ By analyzing Value Added Tax (VAT) data for 25 EU countries, Immordino \& Russo (2018) find a negative relationship between VAT evasion and card payments for the period $2000-2012$. Moreover, using cards to access cash at ATMs makes cash more abundant and fosters VAT evasion. Therefore, they conclude that the use of cashless payment instruments hinders tax evasion. Schneider \& Linsbauer (2016) give a literature review on the finances of international crime organizations which shows that cash is used in many crime activities. Therefore, restrictions of cash have the potential to reduce these activities as transaction costs rise. However, as the private profits of crime activities are very high, the reduction will probably be modest. The general conclusion from all these studies seems to be that the repercussions on cash demand depend on the concrete definition of the shadow economy, the country under investigation and the time period considered.

Our paper differs in several aspects from the existing literature. First, we are the first to use flow-offunds data on private households' cash holdings in each of the 19 euro area countries to analyze the drivers of cash demand within a currency union. Up to now, only the cumulated national net issues are taken as a proxy of cash demand (see for the euro area Bartzsch, et al., 2013; Rua, 2018; Seitz, et al., 2020; for the US, Judson \& Porter, 2001, ch 6.4) or, the euro area as a whole is investigated (see Fischer, et al., 2004; Rua, 2019). Second, and following Seitz, et al. (2020), we distinguish between large and small countries to get information how the results depend on the country grouping. Third, we use estimates of the shadow economy which do not rely on the currency demand approach (see Medina \& Schneider, 2018, ch 3). ${ }^{5}$ This is necessary to circumvent the circularity problem of estimating the shadow economy with cash figures, and in a subsequent step estimating cash demand functions that include as regressor the size of the shadow economy estimated in the first step (see also Herwartz, et al., 2016, 1634f). ${ }^{6}$ Fourth, we take several proxies for cashless payment media on board to map payment innovations. Lippi \& Secchi (2009) argue that it is important to incorporate the effects of technical progress in the transactions technology in cash demand studies to understand households' cash holdings. And Bounie, et al. (2016) as well as Bartzsch, et al. (2019) emphasize that (debit and credit) cards provide two services for consumers - cash withdrawal and payment - that have contrasting effects on cash holdings and cash usage. Bartzsch \& Seitz (2016) use similar variables as we do in the case of Germany and find a marginal significant substitution relationship only for the small denominations. Fifth, we also study whether the access to cash matters. Rua (2019) does this for 
the euro area as a whole in including the number of ATMs in his estimations. This is important against the background of initiatives of banks to optimize their branch structure and to make access to cash more difficult by reducing the number of ATMs (see also Snellman \& Virén, 2009). And finally, we also consider crisis-related and precautionary demand for cash and control for further motives of holding cash by due specification of our econometric model.

From this discussion of the literature, we formulate the following four hypotheses which we will test statistically in the next sections in a unified framework:

(1) The larger the size of the shadow economy in a euro area country, the more cash will be used by households.

(2) The more cash substitutes as payment innovations are available, the less cash will be held.

(3) The drivers of cash demand are independent of the size of the country.

(4) Access to cash is important for consumers to realize their payments preferences.

\section{DATA ISSUES AND ECONOMETRIC METHODOLY}

The cash series we use is households' cash holdings in every euro area country. It is taken from the flow of funds statistics of the Eurosystem (see ECB Statistical Data Warehouse; https://sdw.ecb.europa.eu). It is calculated as a residual by the national central banks (and cross-checked by the ECB to ensure consistency) as follows: total net issuance - external holdings - holdings of the financial sector (e.g., banks) - (negligible) holdings on non-financial corporations $(\mathrm{ECB}, 2005){ }^{7}$ For an illustration of the 5 largest euro area countries see figure 2. Cash holdings of households increased steadily in Germany, Italy and France, whereas they decreased slightly in the Netherlands (from an already low level) and in Spain since the financial crisis 2008. Also evident is the drastic increase in Germany since 2012. The average annual growth rates and standard deviations in the 19 countries vary enormously, between $-0.1 \%$ for the Netherlands and $13.2 \%$ for Luxemburg and $4.8 \%$ for Austria and over $40 \%$ for Latvia (see table $1 \mathrm{~A}$ in the appendix).

FIGURE 2

HOUSEHOLDS' CASH HOLDINGS IN SELECTED EURO AREA COUNTRIES (€ BN)

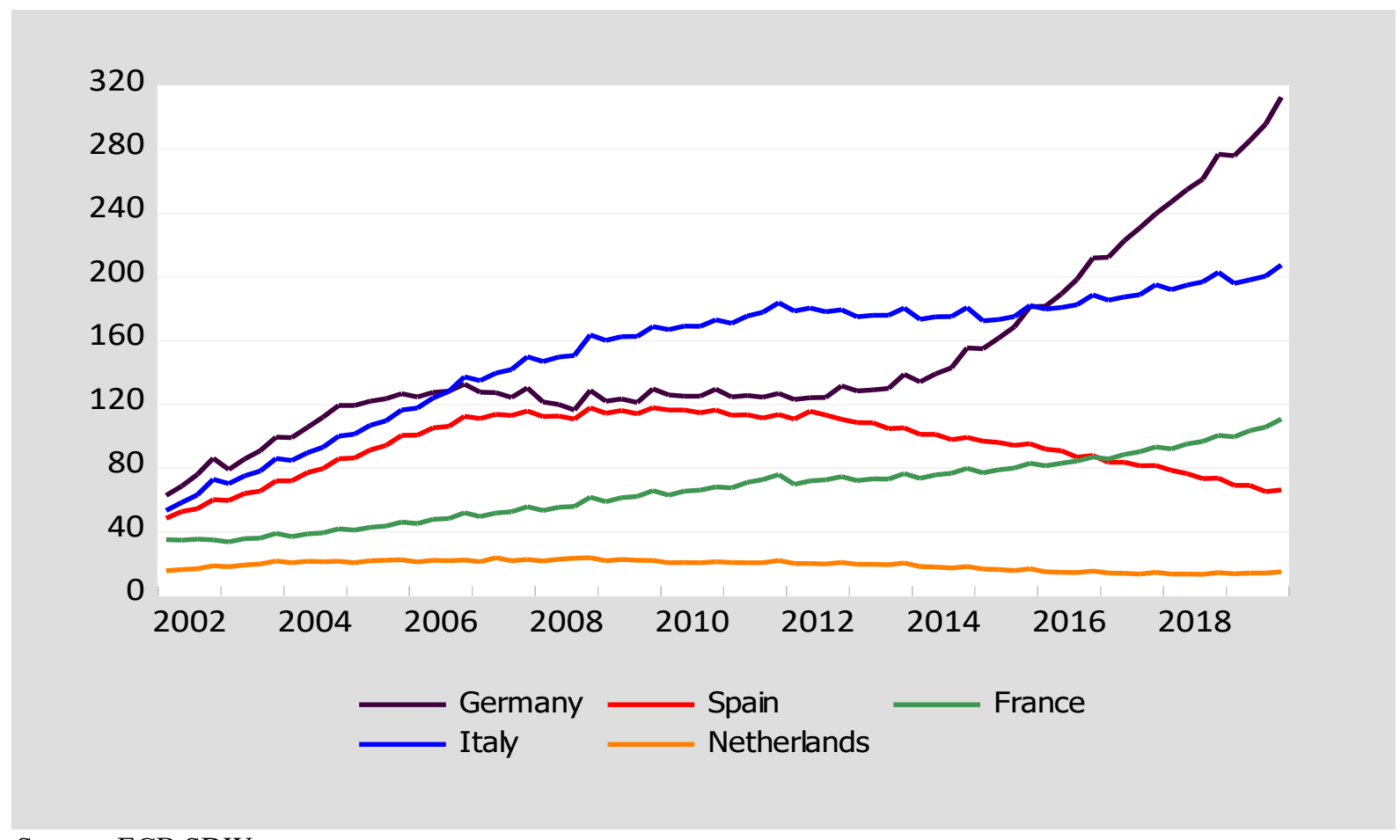

Source: ECB SDW 
The traditional determinants of cash demand are a transactions variable and opportunity costs. As a proxy for transactions, we refer to real private consumption which should be more closely related to cash payments than GDP (see also, e.g., Fischer, et al., 2004; Bartzsch \& Seitz, 2016; Rua, 2018). Our opportunity costs are based on interest rates on all deposits of private households with an agreed maturity. The overwhelming majority of these deposits is within the two-year maturity. The data is from the OECD and the ECB Statistical Data Warehouse, respectively.

Generally, the size of the shadow economy can be measured in two ways: at the micro level using surveys or questionnaires; alternatively, indirect methods such as the currency demand or latent Multiple Indicators Multiple Causes (MIMIC) approach making use of macroeconomic indicators can be used (see, e.g., Medina \& Schneider, 2018, ch 3). The virtue of the latter is that the shadow economy is formalized as the outcome of a multitude of measurable causes like tax rates, the degree of regulation, or the level of unemployment. As we need a time series for every euro area country, we rely on the MIMIC approach. ${ }^{8}$ This model is used to analyze unobservable variables, such as corruption, black market activities. The idea of the MIMIC approach is to examine the relationships between a latent variable, e.g. "size of shadow economy", and observable variables ("indicators") by using their covariance information (Schneider \& Buehn, 2016). The equation capturing the causes of the latent variable is called the structural model, the equation modelling the consequences of the shadow economy is called the measurement model. The measurement model shows how the observable endogenous variables are affected by the latent variables. The structural model expresses the relationship between the latent variable and its exogenous causal variables. Because the latent variable is unobserved, the structural parameters cannot be estimated directly. To avoid the well-known identification problem, the indicator variables we use do not include cash. To be more concrete, we use the following indicator variables in our estimation: (1) the labor force participation rate, (2) the light intensity rate, and (3) the growth rate of GDP (Medina \& Schneider, 2018, chapter 3C). Our estimates for the five largest euro area countries are shown in figure 3. Some further descriptive statistics on all countries are in table 2A in the appendix. As is evident from this table, the highest share of shadow economic activities in our sample can be found in Greece, the lowest share in Austria. The values vary between $9 \%$ and $30 \%$ and have relatively small standard deviations.

Our measure of the shadow economy refers to the hidden economy, i.e., activities that clearly fall in the production boundary of the System of National Accounts, but are deliberately concealed from public authorities to avoid the payment of social security contributions, to avoid having to meet certain legal standards such as minimum wages, maximum hours, safety or health standards, to avoid complying with certain administrative procedures, etc. (UN, et al., 2009, § 6.40). These activities are quite common in the household sector. Examples are baby-sitting, extra tuition for pupils, paying the cleaning woman, repairing a car or building a house. Our conjecture and null hypothesis is that these activities are to a large extent settled in cash.

Journal of Applied Business and Economics Vol. 23(3) 2021321 
FIGURE 3

THE SHADOW ECONOMY IN SELECTED EURO AREA COUNTRIES (\% IN GDP)

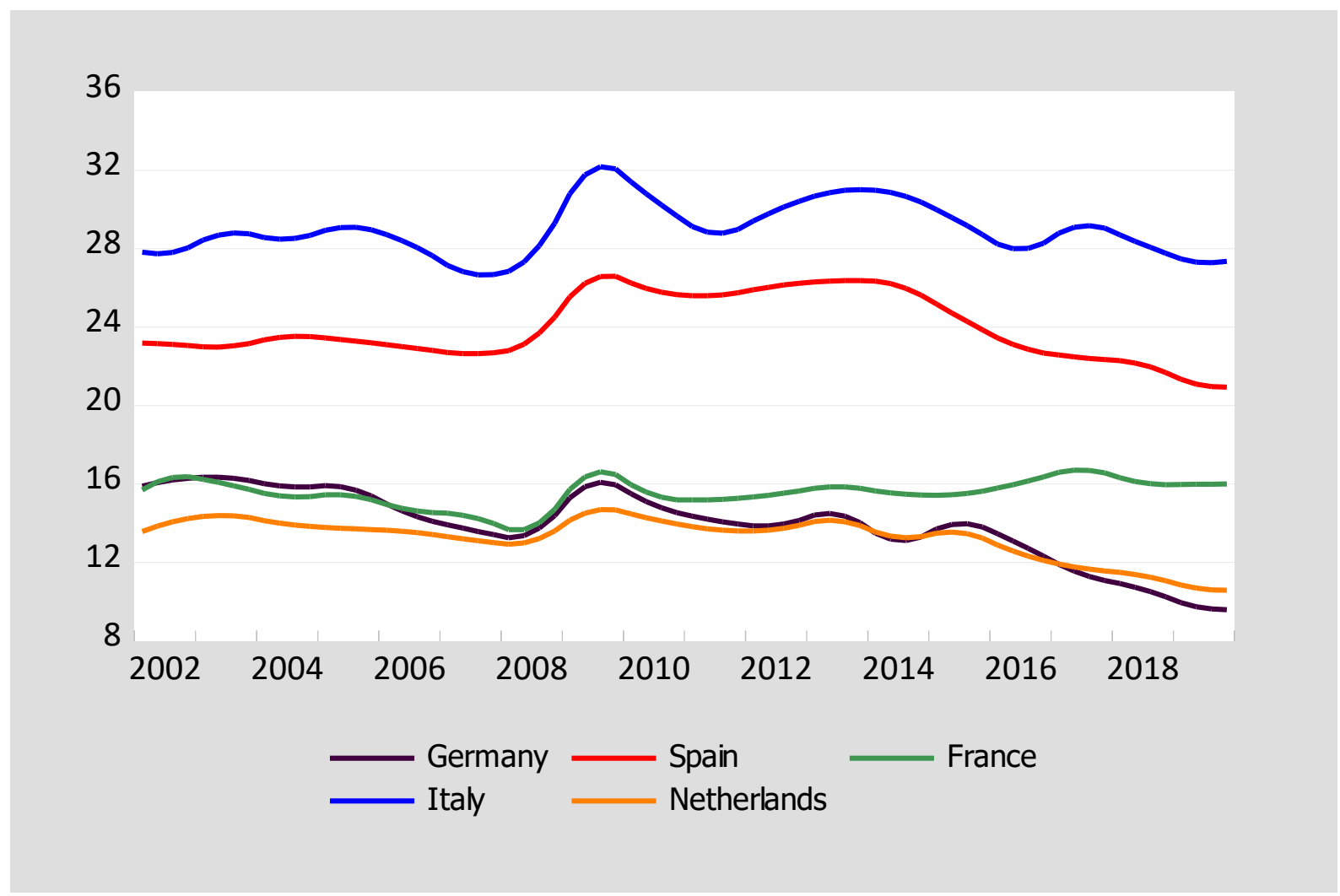

Source: own estimates

The payments innovation variables we use are: the number of (debit and credit) cards, the number and value of card payments and the number and value of cashless POS transactions as proxies of actual or potential cashless alternatives to cash; the number of POS terminals as a proxy for acceptance of cards by retailers; ${ }^{9}$ the number of ATMs as proxy for access to cash. These are also taken from the ECB SDW. These payments data are only available on an annual basis and until 2018. Besides the number of ATMs, we take each variable in turn into account as they all proxy alternatives to cash payments. This procedure allows to discriminate between the quality of the substitution relationship in the cash demand equation.

We consider all euro area countries since they have introduced the euro. Consequently, our quarterly sample runs form 2002q1-2019q4 or shorter, ie we have an unbalanced panel structure. ${ }^{10}$ If data is annual, it is transformed to the quarterly frequency using the Chow-Lin procedure with $\operatorname{AR}(1)$ errors which guarantees smooth estimates. As our sample is quarterly and our data not seasonally adjusted, we use seasonal dummies, if necessary, to model seasonality. All variables, except the shadow economy, are in $\operatorname{logs}$, i.e. we estimate true elasticities. ${ }^{11}$ Table $3 \mathrm{~A}$ in the appendix summarizes all the variables used together with their abbreviations and data sources.

The trend behavior of the variables included necessitates an analysis of their stationarity properties to determine an appropriate specification of the empirical model. However, it is well-known that standard unit root and cointegration tests suffer from a short sample bias, i.e. they have low power against stationary alternatives. Panel tests improve the situation in this respect as they augment the time series dimension by the cross section. Consequently, inference is based on a broader information set with resulting gains in power and more reliable statistical inference.

Our main interest is to establish a meaningful panel cointegration relationship for the different specifications. Thus, the cash demand equations should be statistically significant and economically valid 
in having the theoretically expected signs. As there might be national peculiarities besides the cash motives considered, we estimate the regressions with fixed country effects. And to capture unmodelled dynamics (or omitted variables) in our sample period, we include deterministic country-specific trends in the final estimates.

We proceed as follows:

(1) Test for unit roots (stationarity) of the variables in the panel.

(2) If there is non-stationarity, test for the existence of a (at least one) cointegrating relationship.

(3) If there is evidence for cointegration, may it be interpreted as a cash demand equation.

\section{RESULTS}

Table 1 comprises the results of a battery of panel unit root tests. These include the common root approach of Levin, Lin \& Chu (2002) as well as the method of a common unit root of Breitung (2000). Both approaches share the assumption that there is a common unit root process, which is identical across the cross sections. The respective null hypothesis is the existence of a unit root. The individual unit root approaches of Im, et al. (2003) (IPS) and the two Fisher tests (ADF and PP) combine individual unit root tests to determine a panel test statistic (see, e.g., Maddala \& Wu, 1999). The IPS relies on the t-statistics of the ADF regression. The Fisher-ADF and the Fisher PP use p-values from individual unit root tests. All these approaches allow for individual intercepts to model individual fixed effects or individual intercepts and individual trends. The optimal lag lengths are in each case selected using the Hannan-Quinn criterion (H-Q).

The second column in table 1 indicates the specification of the deterministic part in the test regressions. The coefficients of this part are country-specific. The null hypothesis of a common unit root of the LLC tests is rejected in only a few cases, whereas the more general null of the IPS, ADFF and PPF is usually not rejected for the level variable (similar to the reported Breitung test). However, it is rejected for the change $(d)$ of the variables. Therefore, we conclude that all variables are I(1).

TABLE 1

PANEL UNIT ROOT TESTS

\begin{tabular}{|c|c|c|c|c|c|c|c|}
\hline Variable & $\begin{array}{l}\text { Test } \\
\text { specification }\end{array}$ & LLC & Breitung & IPS & ADFF & PPF & Desicion \\
\hline lcash & intercept + tr & $-1.35^{*}$ & 5.87 & 0.42 & $52.3 *$ & $57.3 * *$ & \multirow[t]{2}{*}{$\mathrm{I}(1)$} \\
\hline $\mathrm{d}($ lcash) & Intercept $+\operatorname{tr}$ & $-20.9 * * *$ & $-1.99 * *$ & $-24.7 * * *$ & $497.2 * * *$ & $811.5 * * *$ & \\
\hline se & intercept + tr & 9.23 & 1.08 & 1.79 & 33.1 & 38.6 & \multirow[t]{2}{*}{$\mathrm{I}(1)$} \\
\hline $\mathrm{d}(\mathrm{se})$ & Intercept + tr & 17.1 & -4.85 & $-7.01 * * *$ & $118.5 * * *$ & $87.5 * * *$ & \\
\hline lcons & intercept $+\operatorname{tr}$ & -0.78 & 0.10 & 0.30 & 27.9 & $292.8 * * *$ & \multirow[t]{2}{*}{$\mathrm{I}(1)$} \\
\hline $\mathrm{d}($ lcons $)$ & Intercept $+\mathrm{tr}$ & 75.8 & $-4.24 * * *$ & $-6.03 * * *$ & $120.9 * * *$ & $697.8 * * *$ & \\
\hline $\operatorname{lin}$ & intercept $+\operatorname{tr}$ & 1.34 & -1.07 & 1.91 & 27.8 & 21.5 & \multirow[t]{2}{*}{$\mathrm{I}(1)$} \\
\hline $\mathrm{d}(\operatorname{lin})$ & Intercept $+\operatorname{tr}$ & $-19.7 * * *$ & $-7.82 * * *$ & $-17.8 * * *$ & $310.7 * * *$ & $337.1 * * *$ & \\
\hline $\operatorname{lnc}$ & Intercept $+\operatorname{tr}$ & $-2.59 * * *$ & 1.20 & -0.79 & 47.3 & $79.8 * * *$ & \multirow[t]{2}{*}{$\mathrm{I}(1)$} \\
\hline $\mathrm{d}(\ln \mathrm{c})$ & Intercept $+\operatorname{tr}$ & 4.56 & $-2.78 * * *$ & $-3.55 * * *$ & $71.8 * * *$ & $81.6^{* * *}$ & \\
\hline $\operatorname{lncp}$ & intercept $+\mathrm{tr}$ & 1.25 & 2.00 & 0.18 & 28.2 & 46.3 & \multirow[t]{2}{*}{$\mathrm{I}(1)$} \\
\hline $\mathrm{d}(\ln c p)$ & Intercept $+\mathrm{tr}$ & 14.6 & $-3.73 * * *$ & $-4.94 * * *$ & $85.4^{* * *}$ & $110.4^{* * *}$ & \\
\hline lvcp & Intercept + tr & 0.17 & 2.98 & -0.09 & 33.1 & 31.7 & \multirow[t]{2}{*}{$\mathrm{I}(1)$} \\
\hline $\mathrm{D}(\mathrm{lvcp})$ & Intercept + tr & 18.9 & $-4.48 * * *$ & $-4.15 * * *$ & $72.7 * * *$ & $107.6 * * *$ & \\
\hline lnoa & intercept $+\mathrm{tr}$ & $-2.63 * * *$ & 3.47 & 3.23 & 20.7 & 21.5 & \multirow[t]{2}{*}{$\mathrm{I}(1)$} \\
\hline $\mathrm{d}($ lnoa $)$ & Intercept $+\mathrm{tr}$ & 6.33 & $-1.37 *$ & $-2.73 * * *$ & $58.0^{* *}$ & $99.7 * * *$ & \\
\hline $\operatorname{lnpt}$ & Intercept $+\operatorname{tr}$ & $-1.53 *$ & 0.79 & 1.18 & 43.9 & $52.7^{*}$ & \multirow[t]{2}{*}{$\mathrm{I}(1)$} \\
\hline $\mathrm{d}(\ln p \mathrm{t})$ & Intercept $+\mathrm{tr}$ & 2.44 & $-2,21 * *$ & $-2.88 * * *$ & $68.9 * * *$ & $107.0 * * *$ & \\
\hline
\end{tabular}




\begin{tabular}{|c|c|c|c|c|c|c|c|}
\hline lnptr & Intercept + tr & 1.78 & 4.43 & 1.49 & 31.3 & 36.1 & \multirow[t]{2}{*}{$\mathrm{I}(1)$} \\
\hline $\mathrm{d}(\operatorname{lnptr})$ & Intercept $+\mathrm{tr}$ & 15.7 & $-5.95 * * *$ & $-5.89 * * *$ & $102.3 * * *$ & $95.7 * * *$ & \\
\hline lvptr & Intercept $+\mathrm{tr}$ & 3.46 & 2.94 & 1.81 & 28.6 & 22.2 & \multirow[t]{2}{*}{$\mathrm{I}(1)$} \\
\hline $\mathrm{d}$ (lvptr) & Intercept + tr & 13.0 & $-7.08 * * *$ & $-7.20 * * *$ & $125.5 * * *$ & $94.3 * * *$ & \\
\hline
\end{tabular}

Notes: 1: log; in: interest rate; cons: private consumption; se: shadow economy; nc: number of cards; v(n)cp: value (number) of card payments, noa: number of ATMs; v(n)ptr: value (number) of EFTPOS transactions; npt: number of POS terminals. d: difference operator. Bandwidth selection using Hannan-Quinn criterion; LLC: Levin, Lin \& Chu tstatistic, Breitung: Breitung t-statistic (only available for specifications with intercept and trend), IPS: Im, Pesaran \& Shin W-statistic, ADFF: ADF-Fisher Chi²-statistic, PPF: PP-Fisher Chi² ${ }^{2}$-statistic; Newey-West automatic bandwidth selection and Bartlett kernel; *** (**,*): $1(5,10)$ percent significance level.

Due to the non-stationarity of the variables, the next natural step is to test for a cointegrating relationship. Pedroni (2004) suggests residual based tests for the null of no cointegration under the assumption of a heterogeneous panel. He suggests two classes of tests. The first is based on pooling the residuals of the Engle-Granger type regression along the within dimension of the panel. Besides the individual approach, cross sectional dependency is taken into account by weighting which uses a generalized least squares method based on the estimation of the panel-wide asymptotic covariance matrix. The second uses the pooling of the residuals adopting the between-dimension of the panel. The test of Kao (1999) follows the same basic approach as the Pedroni tests, but requires homogeneous coefficients of the cointegrating relationship and allows for country-specific intercepts. We use the augmented version of the test. Finally, the combined test (Fisher-Johansen) evaluates the results (p-values) of individual Johansen trace (max. eigenvalue) cointegration tests (see Maddala \& Wu, 1999). The multitude of tests applied (unit root, cointegration) should be regarded as a kind of robustness check of our results. These are presented in tables $2 \mathrm{a}$ and $2 \mathrm{~b}$. It includes the systems containing the variables lcash, se, lin lcons and one of our cashless variables. There is evidence of a cointegrating relationship for all cash specifications. Most of the tests reject the null of no cointegration.

If there is evidence for cointegration, it is of interest whether the relationship might be interpreted as a cash demand equation. Pedroni (2001) suggests a panel estimator for one cointegrating relationship as an extension of the fully modified OLS estimator of Phillips \& Hansen (1990) called panel fully modified OLS (P-FMOLS). The OLS estimator is a super-consistent estimator of the coefficients of cointegrated variables. Often used variants are the Pedroni (2001) and Mark \& Sul (2003) procedures which are based on a consistent estimator of the moments of the regressors. Moreover, the authors propose an extension of the Stock \& Watson (1993) estimator for panels known as panel dynamic OLS (P-DOLS). This estimator uses lags and leads of the explanatory variables to reduce the asymptotic endogeneity and serial correlation. In our case with quarterly data, we restrict the leads and lags to two. ${ }^{12}$ In a simulation study Wagner \& Hlouskova (2012) show that the P-DOLS estimator performs best across a large set of experiments. They confirm evidence of Kao \& Chiang (2001). Therefore, we prefer and present the results of the P-DOLS methodology. ${ }^{13}$ 
TABLE 2A

PANEL COINTEGRATION TESTS (PART 1)

\begin{tabular}{|l|l|l|l|l|l|l|}
\hline Test statistic & \multicolumn{2}{l|}{$\begin{array}{l}\text { Variables: lcash, se, lin, } \\
\text { lcons, lnoa }\end{array}$} & \multicolumn{2}{l|}{$\begin{array}{l}\text { Variables: lcash, se, lin, } \\
\text { lcons, lnc }\end{array}$} & \multicolumn{2}{l|}{$\begin{array}{l}\text { Variables: lcash, se, lin, } \\
\text { lcons, lnpt }\end{array}$} \\
\hline & Individual & Weighted & Individual & Weighted & Individual & Weighted \\
\hline $\begin{array}{l}\text { Pedroni: } \\
\text { Panel } v\end{array}$ & -0.17 & 0.35 & 0.83 & 1.07 & -0.43 & -2.32 \\
\hline Panel $\rho$ & -0.10 & -1.14 & -0.49 & -1.27 & 0.84 & -0.35 \\
\hline Panel PP & $-2.33^{* * *}$ & $-4.23^{* * *}$ & $-2.49^{* * *}$ & $-3.99^{* * *}$ & -1.17 & $-3.48^{* * *}$ \\
\hline Panel ADF & $-2.76^{* * *}$ & $-3.25^{* * *}$ & -0.73 & $-1.85^{* *}$ & 0.90 & 0.41 \\
\hline Group $\rho$ & 0.25 & 0.07 & & 0.25 & $-4.06^{* * *}$ \\
\hline Group PP & $-4.06^{* * *}$ & $-3.92^{* * *}$ & & $-3.45^{* * *}$ & \\
\hline Group ADF & $-3.45^{* * *}$ & $-1.26^{*}$ & $-1.95^{* *}$ & \\
\hline Kao ADF & $-1.95^{* *}$ & $-1.28^{*}$ & $483.0^{* * *}$ & \\
\hline $\begin{array}{l}\text { Fisher Johansen } \\
\text { trace r=0 }\end{array}$ & $483.0^{* * *}$ & $503.1^{* * *}$ & & $313.9^{* * *}$ & \\
\hline $\begin{array}{l}\text { Fisher Johansen } \\
\text { max eigenvalue } \\
\text { r=0 }\end{array}$ & $313.9^{* * *}$ & $316.9^{* * *}$ & & \\
\hline
\end{tabular}


TABLE 2B

PANEL COINTEGRATION TESTS (PART 2)

\begin{tabular}{|c|c|c|c|c|c|c|c|c|}
\hline \multirow[t]{2}{*}{ Test statistic } & \multicolumn{2}{|c|}{$\begin{array}{l}\text { Variables: lcash, se, lin, lcons, } \\
\text { lncp }\end{array}$} & \multicolumn{2}{|c|}{$\begin{array}{l}\text { Variables: lcash, se, lin, lcons, } \\
\text { lvcp }\end{array}$} & \multicolumn{2}{|c|}{$\begin{array}{l}\text { Variables: lcash, se, lin, lcons, } \\
\text { lnptr }\end{array}$} & \multicolumn{2}{|c|}{$\begin{array}{l}\text { Variables: lcash, se, lin, lcons, } \\
\text { lvptr }\end{array}$} \\
\hline & Individual & Weighted & Individual & Weighted & Individual & Weighted & Individual & Weighted \\
\hline $\begin{array}{l}\text { Pedroni: } \\
\text { Panel v }\end{array}$ & -0.32 & 0.45 & -0.46 & -0.05 & -0.56 & 0.34 & -1.17 & -0.53 \\
\hline Panel $\rho$ & -0.32 & -1.12 & -0.08 & -0.12 & 0.09 & -0.12 & 0.87 & 0.77 \\
\hline Panel PP & $-2.44 * * *$ & $-3.59 * * *$ & $-1.97 * *$ & $-2.00 * *$ & $-2.18^{* *}$ & $-2.70 * * *$ & -0.80 & $-1.46^{*}$ \\
\hline Panel ADF & $-1.75^{* *}$ & $-1.33^{*}$ & -1.26 & $-1.80 * *$ & $-2.91 * * *$ & $-2.55 * * *$ & 0.22 & $-1.20^{*}$ \\
\hline Group $\rho$ & \multicolumn{2}{|l|}{0.26} & \multicolumn{2}{|l|}{\begin{tabular}{|l|}
0.73 \\
\end{tabular}} & \multicolumn{2}{|l|}{0.99} & \multicolumn{2}{|l|}{1.71} \\
\hline Group PP & \multicolumn{2}{|l|}{$-3.55 * * *$} & \multicolumn{2}{|l|}{$-2.12 * *$} & \multicolumn{2}{|l|}{$-5.66 * * *$} & \multicolumn{2}{|l|}{$-4.56 * * *$} \\
\hline Group ADF & \multicolumn{2}{|l|}{$-1.45^{*}$} & \multicolumn{2}{|l|}{$-1.33^{*}$} & \multicolumn{2}{|l|}{$-4.33 * * *$} & \multicolumn{2}{|l|}{$-3.11 * * *$} \\
\hline Kao ADF & \multicolumn{2}{|l|}{$-1.82 * *$} & \multicolumn{2}{|l|}{$-1.84 * *$} & \multicolumn{2}{|l|}{-1.16} & \multicolumn{2}{|l|}{-1.17} \\
\hline $\begin{array}{l}\text { Fisher Johan- } \\
\text { sen trace } r=0\end{array}$ & \multicolumn{2}{|l|}{$444.1 * * *$} & \multicolumn{2}{|l|}{$498.2 * * *$} & \multicolumn{2}{|l|}{$553.0 * * *$} & \multicolumn{2}{|l|}{$511.9 * * *$} \\
\hline $\begin{array}{l}\text { Fisher Johan- } \\
\text { sen max } \\
\text { eigenvalue } \\
r=0\end{array}$ & \multicolumn{2}{|l|}{$291.6 * * *$} & \multicolumn{2}{|l|}{$358.9 * * *$} & \multicolumn{2}{|l|}{$355.8 * * *$} & \multicolumn{2}{|l|}{$387.0 * * *$} \\
\hline
\end{tabular}

Notes: Variables definition see Table 1 and Table 3A in the appendix; Individual / weighted: Standard DOLS / estimation accounts for heterogeneity by using cross-section specific estimates of the conditional long-run residual variances to reweight the moments for each cross-section when computing the pooled DOLS estimator. Pedroni tests, Kao test: lag length automatically selected by H-Q criterion, spectral estimation with Bartlett kernel, Newey-West automatic bandwidth selection; Pedroni tests: individual intercept and individual trend; Kao test: individual intercept; Fisher Johansen test: lag length of the dynamic part 2, with intercept and trend in cointegrating equation and no trend in VAR. *** $(* *, *): 1(5,10)$ percent significance level. 
As there is evidence of cointegration between the variables considered, we present the results of the estimated long-run coefficients in table $3 .{ }^{14}$ The equations are normalized on the cash variable. We estimate in each case with fixed effects. And we include a dummy variable for the repercussions of the financial crisis in 2008/09. This crisis had a major influence on cash demand in several euro area countries (see, e.g., ECB, 2018; Deutsche Bundesbank, 2016, 33f). Therefore, disregarding its effects on cash demand might distort our results. We model the financial crisis as either an impulse dummy (with a value of one in 2008q4 and zero otherwise) or a step dummy (taking the value of one from 2008q4 onwards until the end of the sample and zero otherwise). The first variant tries to capture a temporary effect, while behind the second is the idea of a more permanent effect. To take due account of the crisis within our framework, we distinguish between common (restricting the coefficient to be equal across countries) and country-specific effects. The following results emerge (not shown in the table) $:{ }^{15}$ First, it is important to model the crisis in a countryspecific way. For all countries together, we do not find a significant effect of the crisis, neither from the impulse dummy nor from the step dummy. Second, modelling the crisis as temporary yields significant positive effects only for Belgium, France and Italy and a negative effect for Slovakia. Positive impacts are found for nearly all countries except the Netherlands where the effect is negative. Third, the step dummy results and thus a long-lasting effect of the crisis are significantly positive for Austria, France and Ireland, but significantly negative for Germany, Estonia, Latvia, Portugal and Slovenia. The results for Germany are surprising. Deutsche Bundesbank (2016) and Bartzsch, et al. (2019) find significant and long-lasting increases in the net issues of the Deutsche Bundesbank in the course of the Lehman insolvency. Our estimates show that this increase is not due to increased demand by German households.

TABLE 3

\section{COINTEGRATING RELATIONSHIP ESTIMATES - EQUATIONS NORMALIZED ON (THE LOG OF) PRIVATE HOUSEHOLDS' CASH HOLDINGS}

\begin{tabular}{|c|c|c|c|c|c|c|c|}
\hline & (1) & $(2)$ & (3) & $(4)$ & $(5)$ & (6) & (7) \\
\hline lcons & $\begin{array}{l}0.21 * * \\
(.09)\end{array}$ & $\begin{array}{l}0.71 * * * \\
(.11)\end{array}$ & $\begin{array}{l}0.57 * * * \\
(.11)\end{array}$ & $\begin{array}{l}0.56^{* * *} \\
(.09) \\
\end{array}$ & $\begin{array}{l}0.50 * * * \\
(.10)\end{array}$ & $\begin{array}{l}0.61^{* * *}(.09) \\
\end{array}$ & $\begin{array}{l}0.31 * * * \\
(.08)\end{array}$ \\
\hline $\operatorname{lin}$ & - & - & - & - & - & - & - \\
\hline $\mathrm{se}$ & $\begin{array}{l}0.03 * * * \\
(.01)\end{array}$ & $\begin{array}{l}0.03 * * * \\
(.01)\end{array}$ & $\begin{array}{l}0.02 * * * \\
(.01)\end{array}$ & $\begin{array}{l}0.02 * * * \\
(.01)\end{array}$ & $\begin{array}{l}0.03 * * * \\
(.01)\end{array}$ & $\begin{array}{l}0.03 * * * \\
(.01)\end{array}$ & $\begin{array}{l}0.03 * * * \\
(.01)\end{array}$ \\
\hline $\operatorname{lnc}$ & $\begin{array}{l}0.11 * * \\
(.05)\end{array}$ & & & & & & \\
\hline $\operatorname{lnpt}$ & & $\begin{array}{l}-0.20 * * * \\
(.03)\end{array}$ & & & & & \\
\hline lvcp & & & $\begin{array}{l}-0.17 * * * \\
(.04)\end{array}$ & & & & \\
\hline $\operatorname{lncp}$ & & & & $\begin{array}{l}-0.27 * * * \\
(.04)\end{array}$ & & & \\
\hline lvptr & & & & & $-0.01(.02)$ & & \\
\hline lnptr & & & & & & $\begin{array}{l}-0.09 * * * \\
(.02)\end{array}$ & \\
\hline lnoa & $\begin{array}{l}0.32^{* * *} \\
(.05) \\
\end{array}$ & $\begin{array}{l}0.37 * * * \\
(.05) \\
\end{array}$ & $\begin{array}{l}0.33^{* * *} \\
(.04) \\
\end{array}$ & $\begin{array}{l}0.26^{* * *} \\
(.04) \\
\end{array}$ & $\begin{array}{l}0.25^{* * *} \\
(.04) \\
\end{array}$ & $\begin{array}{l}0.23^{* * *} \\
(.05) \\
\end{array}$ & $\begin{array}{l}0.36^{* * *} \\
(.04)\end{array}$ \\
\hline Adj. $\mathrm{R}^{2}$ & 0.99 & 0.99 & 0.99 & 0.99 & 0.99 & 0.99 & 0.99 \\
\hline ste & 0.12 & 0.12 & 0.12 & 0.12 & 0.12 & 0.12 & 0.12 \\
\hline
\end{tabular}

Notes: Variables definition see table 1 and Table 3A in the appendix. Sample: 2002q1-2018q4. Unbalanced panel; pooled DOLS estimates (2) with fixed 2 leads and 2 lags; equations deterministics c as fixed effects using crosssection weights; ste: stand error of regression; $* * *(* *, *): 1(5,10)$ percent significance level. () standard errors, Estimates including country-specific trend, fixed country effects and step dummy for the financial crisis (- 1 since $2008 \mathrm{q} 4,0$ before). 
Some interesting findings emerge from table $3 .{ }^{16}$ First, in nearly all specifications do the variables shown have the correct sign and are significant. However, the interest rate is in no case significant with a negative sign. This is in line with Amromin \& Chakravorti (2009) and Bartzsch \& Seitz (2016), but in contrast to Assenmacher, et al. (2019) and Bartzsch, et al. (2019) who distinguish between different denominational groups of all cash holding sectors, but also to Herwartz, et al. (2016) who model total currency in circulation. Therefore, one reason for our result might be that we are not able to distinguish between different denominations in our framework (see Dunbar \& Jones, 2018 and Seitz, et al., 2020). ${ }^{17}$ Obviously, opportunity costs do not play a major role in total cash holdings of euro area households. This is perhaps not too surprising against the background of the dominance of other determinants of holding cash. Consequently, we removed the interest rate from the equations. Second, the shadow economy variable has the expected positive sign and is highly significant in all specifications. Against the background of the definition of our shadow economy variable (see section 3), this seems intuitively plausible. However, the quantitative importance is modest, given elasticity estimates which range between 0.02 and 0.03 . Therefore, an increase in the size of the shadow economy leads only to a minor increase in cash holdings, ceteris paribus. Third, the transactions variable is highly significant and below 1 . With a value between 0.2 and 0.7 , the consumption elasticity is in line with the famous elasticity of 0.5 of the Baumol-Tobin model (Baumol, 1952; Tobin, 1956). ${ }^{18}$ Fourth, cashless alternatives to cash exert a negative influence no matter how these are measured (see for the euro area as a whole Seitz, et al., 2020, ch 4.3; for Germany Bartzsch \& Seitz, 2016 as well as Bartzsch, et al., 2019; for France Bounie, et al., 2016). Fifth, access to cash via ATMs is important to realize payments preferences (see also Amromin \& Chakravorti, 2009; Assenmacher, et al., 2019; Rua, 2019). Against this background, the policy of banks to reduce the number of ATMs implies supply-driven frictions in the payments process ${ }^{19}$ And last, significant positive country-specific trends (not shown in the table) are found for nearly all countries except the Netherlands where the effect is negative. This reveals the strongly declining cash usage of Dutch households since the introduction of euro cash (see, e.g., Jonker, et al., 2018).

As a robustness check and kind of sensitivity analysis, we divide the whole cross section of countries into the big four countries France, Germany, Italy, Spain (Big 4) and the rest of the smaller euro area countries (other countries). We exemplify the results with specification (2) with the number of POS terminals. In table 4 the first column indicates the panels considered. In general, it seems that the results are not driven by specific countries. In both country groupings, all the variables are still significant with the correct signs. This result is at odds with Seitz, et al. (2020) who use the cumulated net banknote issues of each euro area central bank as the dependent variable. The only thing which is striking is the drastic increase in the transactions elasticity in the case of the large countries. This points to a mis-specified transactions variable or neglected further motives of holding cash. The other specifications (not shown, but available upon request) show in principle similar results. However, there are some more insignificant coefficients in the case of the large countries.

TABLE 4

POOLED COINTEGRATING RELATIONSHIPS: DIFFERENT COUNTRY GROUPINGS

\begin{tabular}{|l|l|l|l|l|l|}
\hline \multirow{2}{*}{ Panel } & \multicolumn{4}{l}{ Explanatory variables } \\
\cline { 2 - 6 } & lcons & $\mathrm{se}$ & $\operatorname{lnpt}$ & $\operatorname{lnoa}$ & $\mathrm{R}^{2}$ \\
\hline Big 4 & $2.99^{* * *}(.22)$ & $0.07 * * *(.01)$ & $-0.19^{* * *}(.06)$ & $0.32^{* * *}(.13)$ & 0.98 \\
\hline Other countries & $0.40^{* * *}(.11)$ & $0.03^{* * *}(.01)$ & $-0.25^{* * *}(.03)$ & $0.33^{* * *}(.05)$ & 0.99 \\
\hline
\end{tabular}

Notes: See table 3.

\section{SUMMARY AND CONCLUSIONS}

The present paper was the first to analyze the determinants of cash demand of private households in the euro area. For that purpose, flow-of-funds data on cash holdings in each euro area country are investigated. It was shown that cash holdings of euro area households are driven by (1) transactions demand, (2) the 
availability of alternative cashless payments media, i.e. payment innovations, (3) the shadow economy, (4) ways to access cash, (5) crisis periods and (6) time trends as a catch-all variable for non-modelled motives for holding cash. The results do not seem to be dependent on specific countries. This implies that the drivers of cash demand are the same, no matter whether big or small countries, northern or southern countries, countries with an affinity to use cash or those in which consumers predominantly pay cashless or in which there is a policy of restricting the use of cash. Our results also confirm the four hypotheses we raised at the beginning.

To ensure a smooth functioning of the cash cycle and the retail payments system, it is important for central banks as well as the commercial banking system to be aware of these developments. This is especially true against the background that the biggest share of cash holdings within the euro area originates from private households.

Unfortunately, the cash data set we used did not allow to distinguish between different denominations. This seems to be important insofar as the drivers of cash demand are different for different denominations (see, e.g., Seitz, at al., 2020; Bartzsch \& Seitz, 2016; Bartzsch, et al., 2019; Rua, 2019). Using the same methodology for estimating the shadow economy, Seitz et al (2020) find that it is the medium denominations which drive the results. However, they use the cumulated national net issues, not cash holdings in the respective countries.

The advance of cashless payment methods incentivize people to substitute cash. Consequently, the widespread use of new payments innovations like contactless and mobile payments will further reduce cash holdings (see Brown et al 2020). It is also common wisdom that every crisis up to now has increased the demand for cash (see, e.g., Rösl \& Seitz, 2021). In this respect, the Covid-19 crisis is special. On the one hand, we saw a decline in transactional demand and a rise of card, especially contactless, payments. On the other side, there was an increase in currency in circulation worldwide, even in Scandinavian countries (e.g., Goodhart \& Ashworth, 2020; Chen, et al., 2020). The euro area, for example, observed the strongest weekly increase in cash demand ever since its existence, even higher than in the course of the Lehman crisis in 2008 (Panetta, 2020).

Again for the first time, our paper found a significant and positive repercussions of the size of the shadow economy in the euro area. The shadow economy is a construct which, by definition, is hard to capture and to estimate. We relied on the MIMIC approach to get consistent estimates from 2002 to 2019. This estimate concentrates on household activities and therefore fits our cash variable very well. All in all, it seems that even if cash is used for payments of shadow economic activities, it is probably used to a smaller extent in the context of shadow economic activities than is often suspected and that abolishing or limiting cash would not be as effective as desired in curbing these activities (Mai, 2016; Schneider \& Linsbauer, 2016).

We summarized all other motives for holding cash with the (deterministic) trend variable which exerted a positive influence on cash demand in nearly all countries in our sample. Future research should focus on trying to find variables that capture these motives. This would enable to analyze and interpret the cash developments even more precisely and shed more light on the still not so "bright box" of cash demand.

\section{ENDNOTES}

1. Against the background of a long-lasting period of very low or even negative interest rates, this might change with respect to banks or insurance companies, as experience from Japan shows. In the course of time, this might also increase the demand for cash by other firms. However, Deutsche Bundesbank (2020) estimates with the help of a survey that in Germany only about $50 \%$ of domestic cash hoardings are due to private households. This figure surely underestimates true hoarding, as Deutsche Bundesbank $(2020,50)$ correctly admits.

2. Different approaches to estimate a country's currency circulation within a monetary union, with an application to the euro area, are presented in Dias (2019).

3. Arguments why abolishing cash (or high denomination banknotes) might not be helpful in reducing shadow economic activities can be found in Krüger \& Seitz (2017), ch 7.1 and Schneider (2016). 
4. In a white paper for "Cash Matters", Dalinghaus (2017) examines a range of institutional, legal, scholarly, policy and news media sources to understand the current state of debate about - and evidence for - the links between cash, crime, and terrorism. It emphasizes that singling out cash when criminal activities depend upon multiple tools and methods is ultimately likely to fail in isolation of restrictions on other tools and methods used by criminals to move money and evade restrictions.

5. Pickhardt \& Sardà (2012) modify this approach by taking due account of hoarded cash and foreign demand for cash.

6. If cash is necessary to get efficient estimates of the shadow economy, this might result in distorted results.

7. Unfortunately, we cannot distinguish between small and large denominations with this data set.

8. The MIMIC model to estimate the shadow economy is used by Dell'Anno \& Solomon (2008), Feld \& Schneider (2010), Schneider \& Enste (2013).

9. Huynh et al (2014) establish that card acceptance exerts a substantial quantitative impact on cash demand.

10. See for an analysis of cash payments and receipts of the cash offices in the US within a panel framework Judson \& Porter (2001, ch 5.2).

11. With respect to interest rates, this log-log specification means we estimate true elasticities. A log-level formulation would yield interest rate semi-elasticities, which vary with the level of interest rates. The lower interest rates, the higher the interest rate semi-elasticity in absolute terms which introduces a non-linearity in the relationship. Theoretical considerations justify this formulation (Mulligan \& Sala-i-Martin, 2000). Moreover, Chadha et al (1998) show that in the case of well-behaved utility functions, such a functional form follows necessarily from the application of first principles.

12. An alternative estimation method would be a vector error correction model. However, this approach is not implementable for panels given the high number of parameters to estimate (see Christiansen et al, 2009).

13. Results of the P-FMOLS case are available upon request.

14. We only show the results with weighting. Results without weighting are similar and are available upon request.

15. Detailed results available upon request. We also tested several dummies for the euro crisis 2011/12 and the decision to no longer produce the $€ 500$ banknote, which, however, did not prove to be significant.

16. Seasonal dummies are not shown in the table as they proved to be insignificant in most cases.

17. Briglevics \& Schuh (2014) find that the interest elasticity of cash demand depends on whether consumers are using credit cards with or without revolving debt.

18. See Alvarez \& Lippi (2007) for a modern version of this model.

19. Lippi \& Secchi (2009) show that both the level and the interest rate elasticity of cash holdings depend on the withdrawal technology available to households.

\section{REFERENCES}

Alvarez, F.E., \& Lippi, F. (2009). Financial innovation and the transactions demand for cash.

Econometrica, 77, 363-402.

Amromin, G., \& Chakravorti, S. (2009). Whither loose change? The diminishing demand for smalldenomination currency. Journal of Money, Credit and Banking, 41, 315-335.

Arango-Arango, C.A., \& Suárez-Ariza N.F. (2019). Digital payments adoption and the demand for cash: New international evidence. Banco de la República de Colombia, Discussion Paper No. 1074.

Ashworth, J., \& Goodhart, C.A.E. (2020). The surprising recovery of currency usage. International Journal of Central Banking, 16, 239-277.

Assenmacher, K., Seitz, F., \& Tenhofen, J. (2019). The demand for Swiss banknotes: Some new evidence. Swiss Journal of Economics and Statistics, 155, article number 14.

Baumol, W.J. (1952). The transactions demand for cash: An inventory theoretic approach. Quarterly Journal of Economics, 66, 545-556.

Bartzsch, N., Rösl, G., \& Seitz, F. (2011a). Foreign demand for Euro banknotes issued in Germany: Estimation using direct approaches. Deutsche Bundesbank Discussion Paper Series 1, No 20/2011.

Bartzsch, N., Rösl, G., \& Seitz, F. (2011b). Foreign demand for Euro banknotes issued in Germany: Estimation using indirect approaches. Deutsche Bundesbank Discussion Paper Series 1, No $21 / 2011$. 
Bartzsch, N., Rösl, G., \& Seitz, F. (2013). Currency movements within and outside a currency union: The case of Germany and the Euro area. The Quarterly Review of Economics and Finance, 53, 393401.

Bartzsch, N., \& Seitz, F. (2016). Cash holdings in Germany and the demand for "German" banknotes: What role Is there for cashless payments? In J. Górka (Ed.), Transforming payment systems in Europe (pp. 111-148). Basingstoke: Palgrave Macmillan.

Bartzsch, N., Schneider, F., \& Uhl, M. (2019). Cash usage in Germany: Macroeconomic estimates on the size of illegal cash usage in Germany. Deutsche Bundesbank Publisher.

Bech, M., Faruqui, U., Ougaard, F., \& Picillo, C. (2018, March). Payments are a-changin' but cash still rules. BIS Quarterly Review, pp. 67-80.

Belke, A., Domnick, C., $\&$ Gros, D. (2017). Business cycle synchronization in the EMU: Core vs. periphery. Open Economies Review, 28, 863-892.

Bounie, D., Abel, F., \& Waelbroeck, P. (2016). Debit card and demand for cash. Journal of Banking \& Finance, 73, 55-66.

Breitung, J. (2000). The local power of some unit root tests for panel data. In B. Baltagi (Ed.), Advances in econometrics, Vol. 15: Nonstationary panels, panel cointegration, and dynamic panels (pp. 161-178). Amsterdam: JAI Press.

Briglevics, T., \& Schuh, S. (2014, March). U.S. consumer demand for cash in the era of low interest rates and electronic payments. European Central Bank, Working Paper Series 1660.

Brown, M., Hentschel, N., Mettler, H., \& Stix, H. (2020). Financial innovation, payment choice and cash demand-Causal evidence from the staggered introduction of contactless debit cards. Oesterreichische Nationalbank, Working Paper 230.

Buiter, W.M. (2009, June). Negative nominal interest rates: Three ways to overcome the zero lower bound. NBER Working Paper 15118.

Chadha, J.S., Haldane, A.G., \& Janssen, N.G.J. (1998). Shoe-leather costs reconsidered. The Economic Journal, 108, 363-382.

Chen, H., Engert, W., Huynh, K.P., Nicholls, G., Nicholson, M., \& Zhu, J. (2020, July). Cash and COVID-19: The impact of the pandemic on the demand for and use of cash. Bank of Canada, Staff Discussion Paper 2020-6.

Christiansen, L., Prati, A., Ricci, L.A., \& Tressel, T. (2009). External balance in low income countries. IMF Working paper No. 221.

Dalinghaus, U. (2017). Keeping cash: Assessing the arguments about cash and crime. Institute for Money, Technology \& Financial Inclusion.

Deutsche Bundesbank. (2016). Cash as a means of payment and a store of value. Annual Report, pp. 2545.

Deutsche Bundesbank. (2018, March). The demand for Euro banknotes at the Bundesbank. Monthly Report, pp. 37-51.

Deutsche Bundesbank. (2019, March). Cash demand in the shadow economy. Monthly Report, pp. 43-58.

Deutsche Bundesbank. (2020, July). Cash hoarding by German households - How much cash do they store and why? Monthly Report, pp. 47-60.

Dias, A. (2019). Estimating a country's currency circulation within a monetary union. In BIS (Ed.), Are post-crisis statistical initiatives completed? Proceedings of the Ninth IFC Conference, IFC Bulletin, p.49.

Drehmann, M., Goodhart, C., \& Krueger, M. (2002). The challenges facing currency usage: Will the traditional transactions medium be able to resist competition from the new technologies? Economic Policy, 34, 195-227.

Dunbar, G.R., \& Jones, C. (2018, May). The (un)demand for money in Canada. Bank of Canada, Staff Working Papers 18-20.

Esselink, H., \& Hernández, L. (2017, November). The use of cash by households in the Euro Area. European Central Bank, Occasional Paper Series, No. 201. 
European Central Bank. (2005). Handbook on quarterly financial accounts for the Euro Area: Sources and methods.

European Central Bank. (2017, April 6). Estimation of Euro currency in circulation outside the Euro Area. Press release, 2017.

European Central Bank. (2018). Trends and Developments in the Use of Euro Cash over the past ten Years. Economic Bulletin, (6), 87-109.

European Central Bank. (2020, March). Financial Integration and Structure in the Euro Area.

FAZ. (2016, April 14). Experten zweifeln an Draghis Bargeldbehauptung.

Feld. L.P., \& Schneider, F. (2010). Survey on the Shadow Economy and Undeclared Earnings in OECD Countries. German Economic Review, 11, 109-149.

Fischer, B., Köhler, P., \& Seitz, F. (2004, April). The demand for Euro Area currencies: Past, present, future. ECB Working Paper No. 330.

Flannigan, G., \& Parsons, S. (2018, March). High-denomination banknotes in circulation: A crosscountry analysis. Reserve Bank of Australia. Bulletin, pp. 14-30.

Goodhart, C.A.E., \& Ashworth, J. (2020, June). Coronavirus panic fuels a surge in cash demand. CEPR DP 14910.

Herwartz, H., Sardà, J., \& Theilen, B. (2016). Money demand and the shadow economy: Empirical evidence from OECD countries. Empirical Economics, 50, 1627-1645.

Huynh, K.P., Schmidt-Dengler, P., \& Stix, H. (2014, September). The role of card acceptance in the transaction demand for money. Bank of Canada, Working Paper 2014-44.

Im, K.S., Pesaran, M.H., \& Shin, Y. (2003). Testing for unit roots in heterogenous panels. Journal of Econometrics, 115, 53-74.

Immordino, G., \& Russo, F.F. (2018). Cashless payments and tax evasion. European Journal of Political Economy, 55, 36-43.

Jobst, C., \& Stix, H. (2017, September). Doomed to disappear? The surprising return of cash across time and across countries. CEPR Discussion Paper No. 12327.

Jonker, N., Hernandez, L., de Vree, R., \& Zwaan, P. (2018). From cash to cards: How debit card payments overtook cash in the Netherlands. De Nederlandsche Bank, Occasional Studies, pp. 161.

Judson, R. (2018). The future of cash in crisis and calm: Demand for US dollar banknotes. In Deutsche Bundesbank (Ed.), War on cash: Is there a future for cash? (pp. 200-248). International Cash Conference 2017, conference volume, Frankfurt am Main.

Judson, R.A., \& Porter, R.D. (2001). Overseas dollar holdings: What do we know? Wirtschaftspolitische Blätter, 4, 431-440.

Kao, C. (1999). Spurious regression and residual-based tests for cointegration in panel data. Journal of Econometrics, 90, 1-44.

Kao, C., \& Chiang, M.H. (2001). Nonstationary panels, cointegration in panels and dynamic panels: A survey. In B.H. Baltagi, T.B. Fomby, \& R.C. Hill (Eds.), Nonstationary panels, panel cointegration, and dynamic panels (Vol. 15, 179-222).

Krüger, M., \& Seitz, F. (2017). The benefits of cash (Module 2). Frankfurt/Main: Fritz Knapp Publisher.

Levin, A., Lin, C.F., \& Chu, C. (2002). Unit root tests in panel data: Asymptotic and finite-sample properties. Journal of Econometrics, 108, 1-24.

Lippi, F., \& Secchi, A. (2009). Technological change and the households' demand for currency. Journal of Monetary Economics, 56, 222-230.

Maddala, G.S., \& Wu, S. (1999). A comparative study of unit root tests with panel data and a new simple test. Oxford Bulletin of Economics and Statistics, 61, 631-52.

Mai, H. (2016, November 23). Cash, freedom and crime: Use and impact of cash in a world going digital. Deutsche Bank Research, EU Monitor Global financial markets.

Mark, N.C., \& Sul, D. (2003). Cointegration vector estimation by panel DOLS and long-run money demand. Oxford Bulletin of Economics and Statistics, 65, 655-680. 
Medina, L., \& Schneider, F. (2018, January). Shadow economies around the world: What did we learn over the last 20 years? IMF Working Paper 18/17.

Mulligan, C.B., \& Sala-i-Martin, X. (2000). Extensive margins and the demand for money at low interest rates. Journal of Political Economy, 108, 961-991.

Panetta, F. (2020). Beyond monetary policy - protecting the continuity and safety of payments during the coronavirus crisis. Blog post 28 April 2020.

Pedroni, P. (2001). Purchasing power parity tests in cointegrated panels. Review of Economics and Statistics, 83, 727-731.

Pedroni, P. (2004). Panel cointegration: Asymptotic and finite sample properties of pooled time series tests with an application to the PPP hypothesis. Econometric Theory, 20, 597-625.

Pickhardt M., \& Sardà, J. (2012). Cash, hoarding and the underground economy. In Deutsche Bundesbank (Ed.), The usage, costs and benefits of cash: Theory and evidence from macro and micro data (pp. 15-45). International Cash Conference 2012, Bonifatius Publisher.

Phillips, P.C.B., \& Hansen, B.E. (1990). Statistical inference in instrumental variables regression with I(1) processes. Review of Economic Studies, 57, 99-125.

Rösl, G., \& Seitz, F. (2021, March). Cash and crises: How a virus stimulates cash demand. IMFS Working Paper 150.

Rua, A. (2018). Modelling currency demand in a small open economy within a monetary union. Economic Modelling, 74, 88-96.

Rua, A. (2019, February). Modelling the demand for Euro banknotes, Banco de Portugal. Working Paper 2019-5.

Sands, P. (2016, February). Making it harder for the bad guys: The case for eliminating high denomination notes. M-RCBG Associate Working Paper Series No 52.

Schneider, F. (2016, July). Payment habits and the use of cash in Austria: An empirical investigation. Working paper.

Schneider, F., \& Buehn, A. (2016, March). Estimating the size of the shadow economy: Methods, problems and open questions. IZA DP No. 9820.

Seitz, F., Reimers, H-E., \& Schneider, F. (2020, June). Cash in circulation and the shadow economy: An empirical investigation for euro area countries and beyond. Journal of Business \& Economic Policy, 7(2), 10-32.

Shirai, S., \& Sugandi, E.A. (2019). What explains the growing global demand for cash? ADBI Working Paper Series, No. 1006.

Snellman, H., \& Virén, M. (2009). ATM networks and cash usage. Applied Financial Economics, 19, 841-851.

Stock, J.H., \& Watson, M. (1993). A simple estimator of cointegrating vectors in higher order integrated systems. Econometrica, 61, 783-820.

Sveriges Riksbank. (2019, November). Payments in Sweden.

Takala, K., \& Virén, M. (2010). Is cash used only in the shadow economy? International Economic Journal, 24, 525-540.

Schneider, F., \& Linsbauer, K. (2016). The financial flows of transnational crime and tax fraud: How much cash is used and what do we (not) know? In C. Beer, E. Gnan, \& U.W. Birchler (Eds.), Cash on trial (pp. 83-107). SUERF Conference Proceedings 2016/1, Larcier.

Tobin, J. (1956). The interest-elasticity of transactions demand for cash. Review of Economics and Statistics, 38, 241-247.

United Nations. (2009). System of National Accounts 2008. New York.

Wagner, M., \& Hlouskova, J. (2012). The performance of panel cointegration methods: Results from a large scale simulation study. Econometric Reviews, 29, 182-223. 
APPENDICES: SOME DESCRIPTIVE STATISTICS

TABLE 1A

EURO AREA HOUSEHOLDS' CASH HOLDINGS (ANNUAL GROWTH RATES, \%)

\begin{tabular}{|l|l|l|l|l|}
\hline & Countries & Mean & Std. Dev. & Obs \\
\hline CASH_AT & Austria & 4.50 & 4.81 & 72 \\
\hline CASH_BE & Belgium & 8.10 & 9.14 & 72 \\
\hline CASH_CY & Cyprus & 5.75 & 5.62 & 60 \\
\hline CASH_DE & Germany & 9.07 & 14.21 & 72 \\
\hline CASH_EE & Estonia & 11.63 & 26.91 & 60 \\
\hline CASH_ES & Spain & 1.76 & 10.60 & 72 \\
\hline CASH_FI & Finland & 8.17 & 6.80 & 72 \\
\hline CASH_FR & France & 5.70 & 5.97 & 72. \\
\hline CASH_GR & Greece & 9.24 & 20.34 & 72 \\
\hline CASH_IE & Ireland & 7.70 & 9.84 & 72 \\
\hline CASH_IT & Italy & 6.49 & 9.30 & 72. \\
\hline CASH_LT & Lithuania & 8.49 & 16.75 & 60 \\
\hline CASH_LU & Luxemburg & 13.19 & 21.83 & 72 \\
\hline CASH_LV & Latvia & 10.95 & 40.96 & 60 \\
\hline CASH_MT & Malta & 6.05 & 25.53 & 60 \\
\hline CASH_NL & Netherlands & -0.12 & 9.44 & 72 \\
\hline CASH_PT & Portugal & 2.90 & 5.09 & 72 \\
\hline CASH_SL & Slovenia & 6.48 & 13.71 & 60 \\
\hline CASH_SK & Slovakia & 10.17 & 23.86 & 60 \\
\hline
\end{tabular}

TABLE 2A

SHADOW ECONOMY IN RELATION TO GDP (SE) IN \%

\begin{tabular}{|l|l|l|l|l|l|}
\hline Variable & Countries & Mean & Minimum & Maximum & Std. Dev. \\
\hline SE_AT & Austria & 9.2 & 6.0 & 12.5 & 2.1 \\
\hline SE_BE & Belgium & 22.8 & 21.6 & 24.0 & 0.7 \\
\hline SE_CY & Cyprus & 24.9 & 22.4 & 26.9 & 1.4 \\
\hline SE_DE & Germany & 13.9 & 9.7 & 16.3 & 1.9 \\
\hline SE_EE & Estonia & 23.9 & 20.6 & 29.6 & 2.5 \\
\hline SE_ES & Spain & 24.0 & 21.1 & 26.4 & 1.7 \\
\hline SE_FI & Finland & 17.6 & 15.5 & 18.9 & 1.0 \\
\hline SE_FR & France & 15.6 & 14.0 & 16.6 & 0.7 \\
\hline SE_GR & Greece & 29.6 & 26.8 & 33.0 & 2.0 \\
\hline SE_IE & Ireland & 15.1 & 11.8 & 16.9 & 1.4 \\
\hline SE_IT & Italy & 29.0 & 26.8 & 31.7 & 1.3 \\
\hline SE_LT & Lithuania & 27.0 & 21.9 & 30.4 & 2.8 \\
\hline SE_LU & Luxemburg & 10.1 & 8.4 & 11.0 & 0.7 \\
\hline SE_LV & Latvia & 21.0 & 17.0 & 25.0 & 2.3 \\
\hline
\end{tabular}




\begin{tabular}{|l|l|l|l|l|l|}
\hline SE_MT & Malta & 24.7 & 22.5 & 26.6 & 1.4 \\
\hline SE_NL & Netherlands & 13.3 & 19.7 & 14.5 & 1.1 \\
\hline SE_PT & Portugal & 22.9 & 20.0 & 25.0 & 1.3 \\
\hline SE_SL & Slovenia & 22.9 & 19.5 & 24.9 & 1.7 \\
\hline SE_SK & Slovakia & 13.4 & 12.3 & 15.8 & 1.0 \\
\hline
\end{tabular}

TABLE 3A

LIST OF VARIABLES

\begin{tabular}{|l|l|l|}
\hline Variable & Description & Data source \\
\hline cash & cash holdings of private households & $\begin{array}{l}\text { European Central Bank Statistical } \\
\text { Data Warehouse (ECB SDW) }\end{array}$ \\
\hline cons & private consumption expenditures & OECD \\
\hline in & $\begin{array}{l}\text { interest rate on all deposits of private } \\
\text { households with an agreed maturity }\end{array}$ & ECB SDW; OECD \\
\hline noa & number of ATMs & ECB SDW \\
\hline nc & number of (debit and credit) cards & ECB SDW \\
\hline $\mathrm{ncp}$ & number of card payments & ECB SDW \\
\hline $\mathrm{npt}$ & number of POS terminals & ECB SDW \\
\hline $\mathrm{nptr}$ & number of EFTPOS transactions & ECB SDW \\
\hline se & Share of shadow economy in GDP (\%) & Medina \& Schneider (2018), update \\
\hline $\mathrm{vcp}$ & value of card payments & ECB SDW \\
\hline $\mathrm{vptr}$ & value of EFTPOS transactions & ECB SDW \\
\hline 1 & log & \\
\hline $\mathrm{d}$ & $\begin{array}{l}\text { Difference operator (first, i.e., quarterly } \\
\text { difference) }\end{array}$ & \\
\hline
\end{tabular}

